\title{
Coeliac disease presenting as osteoporosis and associated autoimmune thyroiditis and transient red cell aplasia
}

\author{
H N Rajaratnam ${ }^{1}$, M Saranapala ${ }^{2}$, C N Antonypillai ${ }^{2}$, R Fernando ${ }^{3}$, M de Silva $^{3}$
}

Journal of the Ceylon College of Physicians, 2011, 42, 37-38

\section{Introduction}

Coeliac disease is a rare cause of secondary osteoporosis. It usually presents with diarrhoea and failure to thrive, following the introduction of wheat to the diet. It can be associated with other auto immune diseases. We report a case of occult coeliac disease presenting with severe osteoporosis and autoimmune thyroiditis in a patient with a history of pure red cell aplasia.

\section{Case report}

A 17-year old girl presented with backache for 3 months. She was short and her height was $135 \mathrm{~cm}$ (below the 3rd centile) and the mid parental height was $155 \mathrm{~cm}$. Her appetite and nutritional intake were normal. There were no gastro intestinal disturbances. She had a diffuse goiter but was clinically euthyroid. At the age of 14 years she had been diagnosed of having pure red cell aplasia which was treated with steroids for 6 months and she had been in remission since then. She was a product of a non-consanguineous marriage and had two normal siblings.

Radiographs of the spine showed severe osteopaenia with collapse of lumbar vertebrae L1, L2, and L3. Bone mineral density (BMD) measured using DXA scan was $0.639 \mathrm{~g} / \mathrm{cm} 2$ (Z score of -5.6 ) indicating low BMD for chronological age. Serum calcium, alkaline phosphatase, renal and liver function tests done to exclude common secondary causes for low BMD were normal. Ig A anti endomysial antibody was positive. Jejunal biopsy revealed crypt hyperplasia with a lymphocytic infiltrate and villous atrophy consistent with coeliac disease (Figure 1). TSH was $6.3 \mathrm{miu} / \mathrm{ml}$ (normal 0.4- $5.5 \mathrm{mu} / \mathrm{l}$ ) and free T4 was $1.2 \mathrm{ng} / \mathrm{dl}$ (normal $0.8-1.8 \mathrm{ng} / \mathrm{dl}$ ). Thyroid peroxidase antibody was over $1000 \mathrm{iu} / \mathrm{ml}$ (normal <35 iu/ml) and the aspiration cytology was compatible with chronic auto immune thyroiditis.

\footnotetext{
${ }^{1}$ Nawaloka Hospital, Colombo

${ }^{2}$ Postgraduate Institute of Medicine, Colombo

${ }^{3}$ Asiri Surgical Hospital, Colombo, Sri Lanka.
}

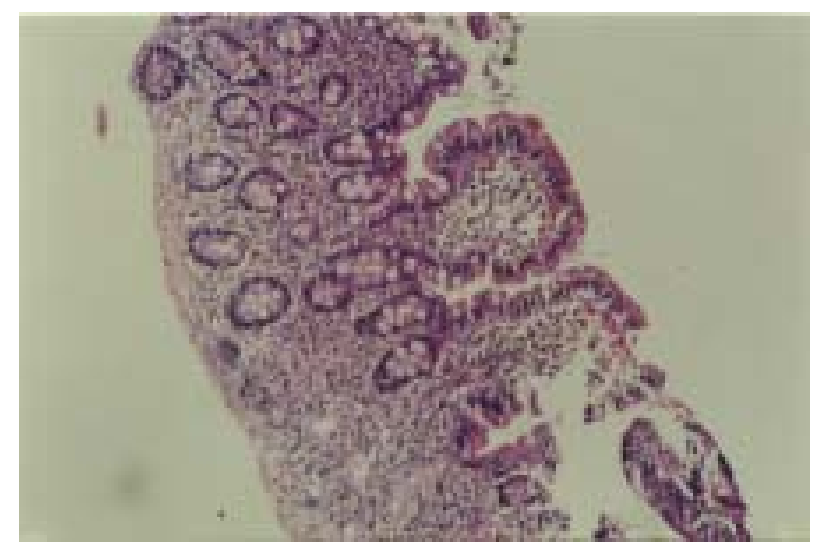

Figure 1. Jejunal biopsy showing crypt hyperplasia with lymphocytic infiltrate and villous atrophy; features consistent with coeliac disease (hematoxylin-eosin; original magnification, $\times 200$ ).

She was started on a gluten free diet and her weight increased by $9 \mathrm{Kg}$ at the end of twelve months along with a sense of improved well being. Alendronate 70 mg weekly was given 2 weeks after starting calcium and vitamin D supplements for the low BMD. A repeat biopsy of the duodenum after 6 months revealed improvement in the histological features. Endomysial antibodies after 1 year of gluten free diet were negative. When the DXA was repeated after 2 years there was an 18\% improvement in BMD (BMD $0.752 \mathrm{~g} / \mathrm{cm}^{2}$ and Z score -3.1).

\section{Discussion}

This patient had very low BMD for her chronological age. Therefore she was investigated for secondary causes of osteoporosis. A 6 month course of steroids for pure red cell aplasia 3 years ago was unlikely to cause this degree of inappropriately low BMD.

Her underlying diagnosis was coeliac disease which was confirmed by the modern criteria viz IgA antiendomysial antibodies which are highly specific and sensitive $\mathrm{e}^{1,2}$ and small bowel biopsy of lymphocytic infiltrate and villous atrophy ${ }^{2,3}$ with clinical and histological improvement following introduction of gluten free diet. Deterioration with re-challenge was previously necessary for diagnosis, but not any longer $^{2,3}$. Patients with coeliac disease previously 
treated with steroids are known to be 'at risk' for developing osteoporosis ${ }^{4}$.

Coeliac disease, an auto immune condition can present in 3 different phenotypes - "classical", "atypical" and "silent"3. "Classical" Coeliac disease presents with diarrhoea, weight loss and gastro intestinal symptoms. The "atypical" variety may present with features other than gastro intestinal symptoms ${ }^{1,3}$. Quite a number of them present to endocrinologists with endocrine disorders including osteoporosis ${ }^{5}$. Unless there is a high degree of suspicion the diagnosis of underlying coeliac disease will be missed. Some adults with coeliac disease may not have any gastrointestinal symptoms ${ }^{1,6}$. This "silent" variety may not be detected unless the tests are done as a part of family screening ${ }^{3}$. This patient did not have any gastro intestinal symptoms but had osteoporosis therefore she belongs to the "atypical" variety of coeliac disease. The disappearance of endomysial antibody and improvement of the intestinal histology with treatment are known.

Our patient also had sub clinical hypothyroid auto immune thyroiditis which is known to be associated with coeliac disease ${ }^{7}$. Pure red cell aplasia though not directly related, has an autoimmune aetiology, may be associated ${ }^{8}$.

\section{Conclusion}

All patients with osteoporosis of obscure cause should be screened for coeliac disease especially if the BMD is age inappropriate. The mechanism of osteoporosis in coeliac disease is uncertain but the prognosis is excellent if the gluten free diet is strictly adhered to ${ }^{7}$.

\section{References}

1. Feighery C. Fortnightly review: coeliac disease. British Medical Journal 1999; 319: 236-9.

2. Marsh MN. Gluten, major histocompatibility complex, and the small intestine. A molecular and immunobiologic approach to the spectrum of gluten sensitivity ('coeliac sprue'). Gastroenterology 1992; 102: 330-54.

3. National Institutes of Health Consensus Development Conference Statement on Coeliac Disease, June 28-30, 2004. Gastroenterology 2005; 128: S1-9.

4. Meyer D, Stavropolous S, Diamond B, Shane E, Green PH, Osteoporosis in a north american adult population with coeliac disease. American Journal of Gastroenterology 2001; 96: 112-9.

5. Fisher AH, Lomasky SJ, Fisher MJ, Oppenheim YL, et al. Coeliac disease and the endocrinologist: a diagnostic opportunity. Endocrine Practice 2008; 14: 381-8.

6. Rostami K, Kerckhaert J, Tiemessen R, von Blomberg BM, Meijer JW, Mulder CJ, Sensitivity of antiendomysium and antigliadin antibodies in untreated coeliac disease: disappointing in clinical practice. American Journal of Gastroenterology 1999; 94: 888-94.

7. West J, Logan RF, Smith CJ, Hubbard RB, Card TR, Malignancy and mortality in people with coeliac disease: population based cohort study. British Medical Journal 2004; 329: 716-9.

8. Couderc AL, Costello $R$, Bagnères $D$, Rossi $P$, Vitton $V$, Demoux AL, Bonin-Guillaume S, Francès Y, Granel B, et al. [Is pure red cell aplasia a new extra digestive manifestation of coeliac disease?]. La Revue de medecine interne / fondee 2006; 27: 336-9. 